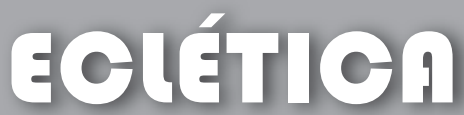 química
}

\section{DEVELOPMENT AND VALIDATION OF SPECTROSCOPIC METHODS FOR SIMULTANEOUS ESTIMATION AND DISSOLUTION OF OFLOXACIN AND ORNIDAZOLE IN TABLET DOSAGE FORMS}

\author{
R.C. Mashru, S.V. Saikumar* \\ Centre of Relevance and Excellence in Novel Drug Delivery System, Pharmacy Department, The Maharaja Sayajirao University of \\ Baroda, G.H. Patel Building, Donor’s Plaza, Fatehgunj, 390002, Vadodara, India \\ ssvaikumar@gmail.com
}

\begin{abstract}
The aim of this work was to develop and validate simple, accurate and precise spectroscopic methods (multicomponent, dual wavelength and simultaneous equations) for the simultaneous estimation and dissolution testing of ofloxacin and ornidazole tablet dosage forms. The medium of dissolution used was $900 \mathrm{ml}$ of $0.01 \mathrm{~N} \mathrm{HCl}$, using a paddle apparatus at a stirring rate of $50 \mathrm{rpm}$. The drug release was evaluated by developed and validated spectroscopic methods. Ofloxacin and ornidazole showed 293.4 and $319.6 \mathrm{~nm}$ as $\lambda_{\text {max }}$ in $0.01 \mathrm{~N} \mathrm{HCl}$. The methods were validated to meet requirements for a global regulatory filing. The validation included linearity, precision and accuracy. In addition, recovery studies and dissolution studies of three different tablets were compared and the results obtained show no significant difference among products.
\end{abstract}

Keywords: Dissolution $\bullet$ Ofloxacin $\bullet$ Ornidazole $・$ Spectroscopy $\bullet$ Simultaneous estimation

\section{Introduction}

Chemically ofloxacin ( OFL, Fig. 1) is ( \pm ) 9-fluoro-2,3, dihydro-3-methyl-10-(4-methyl-1-piperazinyl)-7-oxo-7H-pyrido[1,2,3-d,e]-1,4-benzoxazine-6-carboxylicacid, belongs to new generation of synthetic fluorinated quinolone, structurally related to nalidixic acid [1-3]. This agent is a new broad spectrum antibacterial drug active against most Gram-negative, Gram-positive bacteria, and some anaerobes [4]. Its bacterial action is based on its anti-DNA gyrase activity [5]. This broad spectrum of antibacterial activity and widespread distribution to most tissues and body fluids at relatively high concentrations after oral administration have made this drug useful for the treatment of systemic infections including urinary tract, respiratory, and gastro-intestinal infections [6-8]. Ornidazole (ORN fig. 2)1-(3-chloro-2hydroxy)-propyl-2-methyl-5-nitroimidazole, is a nitroimidazole derivative with antiprotozoal and antibacterial properties. It is used for the treatment and prophylaxis of infections, which is induced by anaerobic and microaerophilic bacteria and protozoa [9].

Combinations of ofloxacin and ornidazole are available in the market, which are highly active against many bacterial infections of enteritis and anaerobic bacteria [23]. Both Ofloxacin and Ornidazole are almost completely absorbed from the small intestine when administered orally both having almost 100\% bioavailability. Subsequent 
plasma concentrations of Ofloxacin are obtained in 1-2 hours after oral administration. Peak plasma concentrations of Ornidazole are obtained within 2 hours of administration. Drug absorption from a dosage form after oral administration depends on the release of the drug from the pharmaceutical formulation, the dissolution and/or its solubilisation under physiological conditions, and the permeability across the gastrointestinal tract. Because of the critical nature of the first two of these steps, in vitro dissolution may be relevant to the prediction of in vivo performance [10-12]. The dissolution test is a very important tool in drug development and quality control.

Dissolution is an official test used by pharmacopoeias for drug evaluation release of solid and semisolid dosage forms, and it is routinely used in Quality Control (QC) and Research \& Development (R\&D). The purpose of in vitro dissolution studies in QC is batch to batch consistency and detection of manufacturing deviation while in $\mathrm{R} \& \mathrm{D}$ the focus is to provide some predictive estimate of the drug release in respect to the in vivo performance of a drug product. For $\mathrm{QC}$, an over-discriminatory test might be suitable to detect even small production deviations. However, for prediction of the in vivo performance of drug product a dissolution test should be sensitive and reliable [12]. The accomplishment of dissolution profiles is recommended as support in the development and optimization of drug formulation as well as in the establishment of in vitro/in vivo correlation. When dissolution test is not defined in the monograph of the dosage form, or if the

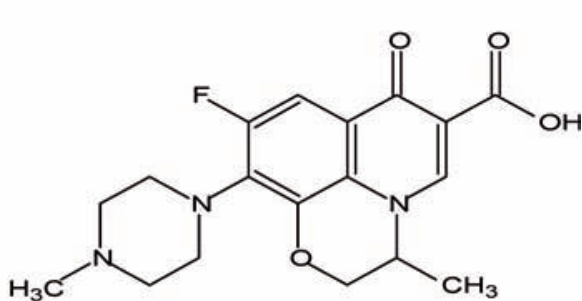

Figure 1. Chemical structure of ofloxacin monograph is not available, the selection of a dissolution medium may be based on the solubility data and dosage range of the drug product [10] Hydrochlonic acid is typical medium m was selected. Typical acceptance criteria for the amoun of drug dissolved are in the range of $70-80 \%$ dissolved [12].

OFL is official in BP [13], USP [14] and EP [15]. The assay procedure mentioned in these pharmacopoeias is non aqueous titration. There are many reported HPLC [16-18], UV spectrophotometry [19] and spectrofluorimetry methods for the estimation of these drugs from pharmaceutical preparations and biological fluids, and also the Canticty [20] Phe of 23] 23] methods are available for the estimation of this combination. At present, there are no official monographs for OFL and ORN dosage forms and no dissolution tests have been described in literature. Parameters to set up the dissolution test should be researched and defined for drugs that do not possess official monographs [12]. The present paper describes the development and validaion of antical methods for the estimation and (ist and dissolution test for OFL and ORN tablet dosage form. The best dissolution conditions were used to valuate the dissolutions testing of three differen brands of tablets.

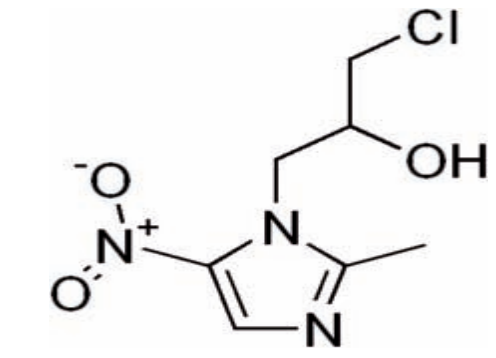

Figure 2. Chemical structure of ornidazole.

\section{Materials}

Ofloxacin and ornidazole chemical reference substances (CRS) (assigned purity 99.7 \& 99.8\%) were obtained from GLPL (Vadodara, India). Tablets were purchased at the local marke and were claimed to contain $200 \mathrm{mg}$ OFL and 500mg ORL each. All reagents and solvents use were analytical grade. Distilled water obtained from a Lab Sil Water Distillation Unit (Bangal werion $0.01 \mathrm{M} \mathrm{HCl}$ solution was prepared acording to USP Pharmacopoeia [14]

\section{Instrumentation}

Dissolution test was performed in a Veego dissolution test system, model VDA 6DR multi-bath ( $\mathrm{n}=6)$, in accordance to USP Pharmacopoeia [14] general method. The mediums were vacuum degassed under house vacuum and were maintained at $37.0 \pm 0.5^{\circ} \mathrm{C}$ by using a thermostatic bath. A double-beam UV-Vis spectrophotometer (Shimadzu, Japan) model UV - 1700 PC, with a fixed slit width $(1 \mathrm{~nm})$ using $1.0 \mathrm{~cm}$ quartz cells was used for all absorbance measurements.

\section{Stock solutions}

OFL and ORN are present in 2:5 ratio in commercial dosage forms, hence stock solution of OFL $(100 \mu \mathrm{g} \mathrm{ml})$ and ORN $(250 \mu \mathrm{g} \mathrm{ml})$ were prepared in $0.01 \mathrm{~N} \mathrm{HCl}$ by dissolving $10 \mathrm{mg}$ and $25 \mathrm{mg}$ of drug in solvent, and volume made up to $100 \mathrm{ml}$ of drug in solvent, and volume made up to $100 \mathrm{ml}$ with $0.01 \mathrm{~N} \mathrm{HCl}$. Appropriate dilutions were made
to the stock solution with distilled water to get the working standard solutions in the same linearity ranges for all three methods.

\section{Sample solutions}

Average weight of twenty tablets was deermined and these tablets were crushed to fine powder. The powder sample equivalent to $10 \mathrm{mg}$ of Ofloxacin and 25mg of Ornidazole was weighed and transferred to $100 \mathrm{ml}$ volumetric flask and dis- solved in $0.01 \mathrm{~N} \mathrm{HCl}$. The content was sonicated for 10min; finally the volume made up to the mark with $0.01 \mathrm{~N} \mathrm{HCl}$ and filtered through Whatmann's filter paper. The filtered solution was suitably diluted with distilled water to obtain mixed standards in the linearity range for each drug. The sample solutions were scanned in the selected wavelength region for respective methods, an the results were obtained are reported in the table.

Development of UV spectroscopic methods for the simultaneous estimation

Three simple, accurate spectrophotometric methods Multi component, Dual wavelength, Simultaneous equations have been developed for the simultaneous determination and dissolution studies of Ofloxacin and Ornidazole in tablet dosage forms. Ofloxacin shows absorption maximum at $293.4 \mathrm{~nm}$ and Ornidazole shows at $319.6 \mathrm{~nm}$ in $0.01 \mathrm{~N} \mathrm{HCl}$. Beer's law was obeyed in the concentration range of 2-12 $\mu \mathrm{g} \mathrm{ml}$ for Ofloxacin and 5-30 $\mu \mathrm{g} \mathrm{ml}$ for Ornidazole.

\section{Method 1: Multi component analysis}

Two sampling wavelengths $293.4 \mathrm{~nm}$ fo Ofloxacin and 319.6nm for Ornidazole were selected for the estimation in the multicomponent mode in the instrument. The absorbance spectra of mixed standards and sample solutions were measured at selected wavelength.

\section{Method 2: Dual wavelength method}

For estimation of one component, two wave lengths were selected, where the absorbances of other component were same. Therefore the difference in the absorbances in the mixed spectra at the corresponding wavelength will be directly proportional to the concentration of that component. For Ofloxacin, 303.2nm $\left(\lambda_{1}\right)$ and 334.6( $\left.\lambda_{2}\right)$ $\mathrm{nm}$, for Ornidazole $284.4 \mathrm{~nm}\left(\lambda_{1}\right)$ and $300.8\left(\lambda_{2}\right)$ were selected. The difference in the absorbances at the selected wavelengths, were plotted against the respective concentration to obtain the calibration curves. The concentration in sample solutions 
of each component was obtained from the calibration curves of the respective drugs.

Method 3: Simultaneous equations method

The absorbances of the both the drugs at both wavelengths (respective absorption max mums $293.4 \mathrm{~nm}$ and 319.6nm) were measured, and the absorptivity and molar absorptivity values were determined for OFL and ORN.

\section{Dissolution test conditions}

Dissolution testing was carried out according to conventional dissolution procedures recommended for immediate release products, using paddle (USP Apparatus 2) at $50 \mathrm{rpm}$. Sampling aliquots of $5.0 \mathrm{ml}$ were withdrawn at 0,15 , 30,45 and 60 minutes, and replaced with an equal volume of the fresh medium to maintain a constant total volume. After the end of each test time, samples aliquots were filtered, diluted in distilled water, when necessary, and quantified. The assay of the three tested products was performed using previously developed and validated spectrophotopretric methods. The contents resuls were used to metric dissolution profile. The cumulative percentage of drug dissolved was plotted against time.

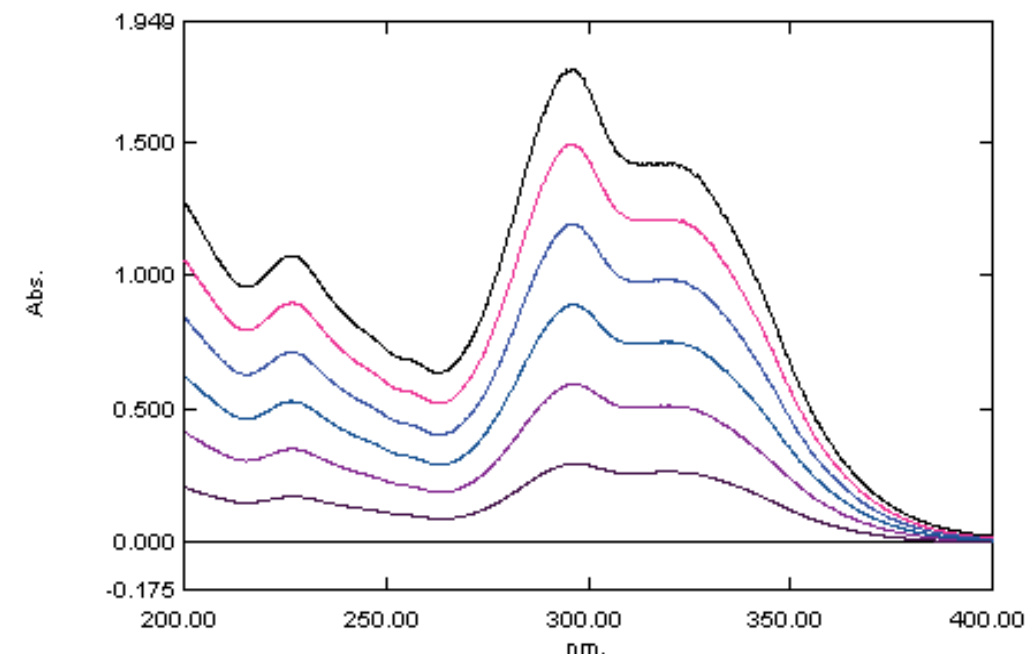

Figure 3. Overlay spectrum of mixture containing OFL and ORN $(2+5$ to12+30 ug/ml)

The developed UV spectrophotometric meprecision, accuracy, and the dissolution study in medium $0.01 \mathrm{M} \mathrm{HCl}$ was validated for precision delines.

$120 \%$ levels on a pre analysed tablet percent recovery of Ofloxacin an of mixture $(2 \mathrm{ug} / \mathrm{ml}$ of OFL $+5 \mathrm{ug} / \mathrm{ml}$ of $\mathrm{ORN}$, to ces OFL (2-12 ug/ml) and ORL (5-30 ug/ml), shown as Figure 4.

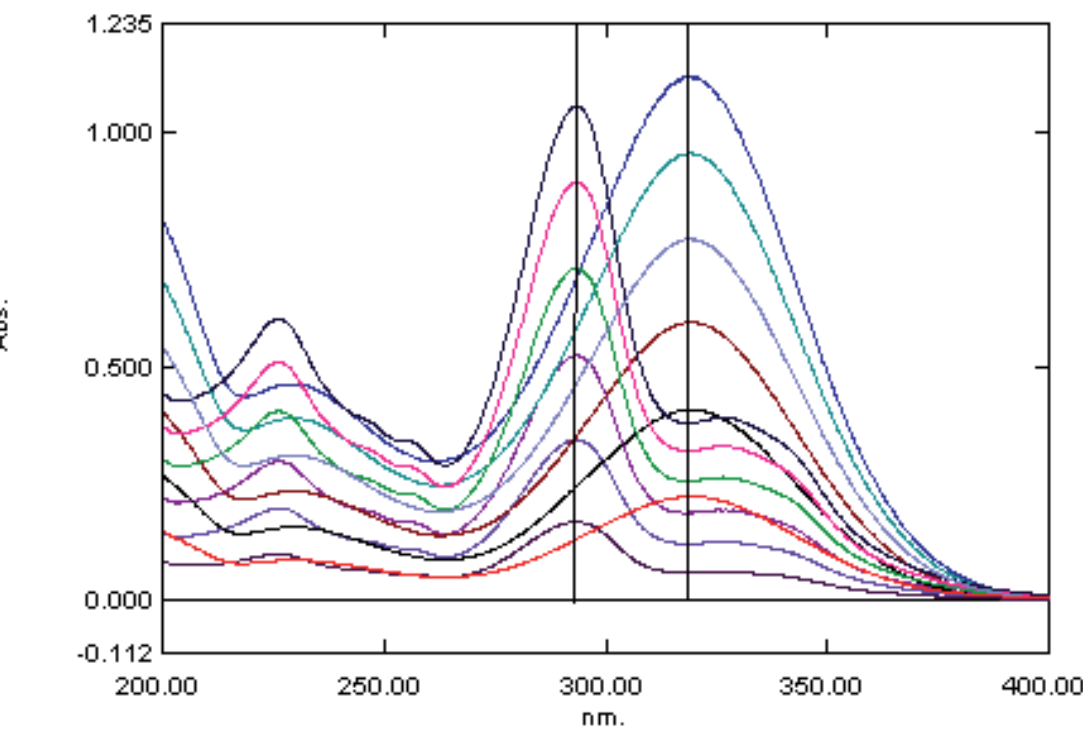

Figure 4. Overlay spectrum of ofloxacin (2-12 ug/ml) and ornidazole (5-30 ug/ml)

\section{Method validation}

The developed methods were validated for linearity, accuracy and precision.

Accuracy of the method was found on the basis of bias measurement and the precision of the method was determined by measuring the repeatability (intra-day precision) and the intermediate precision (inter-day precision), both expressed as RSD (\%).The results were shown in tables $1 \& 2$.

Table 1. Validation parameters includes linearity, limits of detection and quantifications

\begin{tabular}{|c|c|c|c|c|c|c|}
\hline \multicolumn{7}{|c|}{ Regression and analytical parameters } \\
\hline \multirow[t]{2}{*}{ Parameter } & \multicolumn{2}{|c|}{ Multi component method } & \multicolumn{2}{|c|}{ Dual wavelength method } & \multicolumn{2}{|c|}{ Simultaneous equation method } \\
\hline & \multicolumn{2}{|c|}{ Mixture } & OFL & ORN & OFL & ORN \\
\hline$\lambda \max / \mathrm{nm}$ & \multicolumn{2}{|c|}{$296 \mathrm{~nm}$} & $293.4 \mathrm{~nm}$ & $319.6 \mathrm{~nm}$ & 293.4nm & $319.6 \mathrm{~nm}$ \\
\hline Linearity, $\mu \mathrm{g} / \mathrm{ml}$ & $2-12 \mu \mathrm{g}$ & $5-30 \mu g$ & $2-12 \mu \mathrm{g}$ & $5-30 \mu \mathrm{g}$ & $2-12 \mu \mathrm{g}$ & $5-30 \mu g$ \\
\hline $\mathrm{LOD}, \mu \mathrm{g} / \mathrm{ml}$ & 0.065 & 0.16 & 0.082 & 0.15 & 0.082 & 0.15 \\
\hline $\mathrm{LOQ}, \mu \mathrm{g} / \mathrm{ml}$ & 0.22 & 0.54 & 0.27 & 0.48 & 0.27 & 0.48 \\
\hline \multicolumn{7}{|c|}{ Regression equation, $\mathrm{y}^{*}$} \\
\hline Intercept (a) & 0.592 & 0.1481 & 0.0293 & 0.0111 & 0.1464 & 0.0462 \\
\hline Slope (b) & 0.0018 & 0.0018 & -0.003 & 0.0283 & -0.0041 & 0.048 \\
\hline Correlation coefficient (r) & 0.9999 & 0.9999 & 0.9996 & 0.9968 & 0.9999 & 0.9992 \\
\hline
\end{tabular}

$* y=a+b x$, where $y$ is the absorbance and $x$ the concentration in $\mu \mathrm{g} \mathrm{ml}^{-1}$ 
Table 2. Validation results includes accuracy and precision

\begin{tabular}{ccccccc}
\hline \multirow{2}{*}{$\begin{array}{c}\text { Taken } \\
(\text { ug } / \mathrm{ml})\end{array}$} & \multicolumn{5}{c}{ Intra-day $^{\mathrm{a}}$} \\
\cline { 2 - 7 } Found $^{\mathrm{c}}$ & Precision $^{\mathrm{d}}$ & Accuracy $^{\mathrm{e}}$ & Found $^{\mathrm{c}}$ & Precision $^{\mathrm{d}}$ & Accuracy $^{\mathrm{e}}$ \\
\hline OFL 6 & $6.03 \pm 0.07$ & 1.15 & 0.48 & $6.07 \pm 0.16$ & 1.57 & 1.25 \\
ORN 15 & $15.08 \pm 0.17$ & 1.15 & 0.55 & $15.20 \pm 0.39$ & 0.62 & 1.32 \\
\hline \multicolumn{7}{c}{ AULTI COMPONENT METHOD $^{\mathrm{b}}$} \\
\hline OFL 6 & $6.02 \pm 0.03$ & 0.5 & 0.31 & $6.04 \pm 0.02$ & 0.32 & 0.63 \\
ORN 15 & $15.14 \pm 0.2$ & 1.12 & 0.36 & $15.21 \pm 0.25$ & 0.35 & 0.95 \\
\hline \multicolumn{7}{c}{ SIMULTANEOUS EQUATION METHOD } \\
\hline OFL 6 & $6.15 \pm 0.36$ & 1.14 & 0.45 & $6.20 \pm 0.12$ & 1.62 & 0.75 \\
ORN 15 & $15.31 \pm 0.21$ & 1.26 & 0.94 & $15.24 \pm 0.36$ & 1.25 & 0.54 \\
\hline
\end{tabular}

${ }^{\mathrm{a}} \mathrm{n}=6$; ${ }^{\mathrm{b}} \mathrm{n}=6$; ${ }^{\mathrm{c}}$ mean \pm standard error; ${ }^{\mathrm{d}}$ relative standard deviation, \%; ${ }^{\mathrm{e}}$ bias \%:

(found - taken/taken) $\times 100$

Estimation by spectroscopic methods

For the multicomponent and dual wavelength methods, calibration curves were prepared lengths selected, and were used for the measurement of samples.

Determination by simultaneous equations method

The absorptivity values and molar absorptivity values for OFL and ORN are determined (shown in Table 3) and molar absorptivity values for OFL at 293.4 and $319.6 \mathrm{~nm}$ were 31589.37 and $11331.30 \mathrm{~cm}^{-1} \mathrm{~mol}^{-1} \mathrm{lit}^{-1}$, while respective vand 11331.30 $\mathrm{cm}^{-1} \mathrm{nol}^{-1} 1 \mathrm{t}^{-1}$, while respective values for ORN at 293.4 and 319.6 nor 5351.96 and $8706.18 \mathrm{~cm}^{-1}$ mol $^{-1}$ lit 1 . Molecular weight of 0 rt and ORN is 361.4 and 219.625 respectively.

$$
\mathrm{A} 1=5351.96 \mathrm{C} 1+31589.37 \mathrm{C} 2
$$

where A1 and A2 are the values of absorbance of sample at 293.4 and $319.6 \mathrm{~nm}$ respectively, and $\mathrm{C} 1$ and $\mathrm{C} 2$ are concentrations of OFL and ORN in moles lit ${ }^{-1}$ respectively.
Table 3. Absorptivity values of OFL and ORN for simultaneous equations method

\begin{tabular}{cccccc}
\hline \multirow{2}{*}{ Conc $(\mu \mathrm{g} / \mathrm{ml})$} & \multicolumn{2}{c}{ Absorptivity for OFL } & $\begin{array}{c}\text { Conc }(\mu \mathrm{g} / \\
\mathrm{ml})\end{array}$ & \multicolumn{2}{c}{ Absorptivity for ORN } \\
\hline & $293.4 \mathrm{~nm}$ & $319.6 \mathrm{~nm}$ & & $293.4 \mathrm{~nm}$ & $319.6 \mathrm{~nm}$ \\
2 & 874.00 & 314.00 & 5 & 244.00 & 399.00 \\
4 & 873.50 & 314.50 & 10 & 244.25 & 397.00 \\
6 & 873.33 & 313.33 & 15 & 245.33 & 396.67 \\
8 & 874.00 & 312.00 & 20 & 242.50 & 396.00 \\
10 & 876.00 & 312.90 & 25 & 243.20 & 395.80 \\
12 & 873.67 & 314.50 & 30 & 242.83 & 394.00 \\
Mean & 874.08 & 313.54 & Mean & 243.69 & 396.41 \\
S.D & 0.98 & 0.99 & S.D & 1.05 & 1.64 \\
R.S.D & 0.11 & 0.32 & R.S.D & 0.43 & 0.41 \\
M.A * & 31589.37 & 11331.30 & M.A * & 5351.96 & 8706.18 \\
\hline
\end{tabular}

*M.A. is molar absorptivity in $\mathrm{cm}^{-1}$ moles $^{-1}$ lit $^{-1}$ determined from mean value of absorptivity

Three different tablet dosage forms were analysed by the developed methods and the results were shown in table 4 . Recovery studies carried out on the pre analyzed tablets and the results were shown in table 5.

Table 4. Results for OFL and ORN in three different tablet dosage forms

\begin{tabular}{ccccc}
\hline \multirow{2}{*}{ Dosage form } & \multirow{2}{*}{ Labelled amount (mg) } & \multicolumn{3}{c}{ Found $^{\text {a }}$ (\% of nominal amount \pm SD) } \\
& & METHOD 1 & METHOD 2 & METHOD 3 \\
\hline ORNI O & OFL 200 & $98.85 \pm 1.45$ & $99.27 \pm 2.17$ & $98.28 \pm 0.68$ \\
Tablet & ORN 500 & $102.71 \pm 1.10$ & $101.21 \pm 1.50$ & $98.21 \pm 1.44$ \\
OSNO O & OFL 200 & $99.76 \pm 0.86$ & $99.16 \pm 1.69$ & $100.74 \pm 1.62$ \\
Tablet & ORN 500 & $101.68 \pm 1.45$ & $101.32 \pm 1.64$ & $98.35 \pm 1.73$ \\
OFLOX OZ & OFL 200 & $101.22 \pm 1.86$ & $101.87 \pm 1.54$ & $102.75 \pm 1.71$ \\
Tablet & ORN 500 & $102.32 \pm 1.54$ & $101.61 \pm 1.55$ & $97.97 \pm 1.81$ \\
\hline
\end{tabular}

Method 1 - Multicomponent method

Method 2 -Dual wave length method

Method 3- Simultaneous Equation method

${ }^{a}$ Mean value of six determinations 
Table 5. Recovery results for OFL and ORN by using three different tablet dosage forms

\begin{tabular}{|c|c|c|c|c|c|c|c|c|}
\hline \multicolumn{9}{|c|}{ MULTICOMPONENT METHOD } \\
\hline Dosage form & $\begin{array}{l}\text { OFL in } \\
\text { dosage form } \\
(\mu \mathrm{g} / \mathrm{ml})\end{array}$ & $\begin{array}{l}\text { ORN in } \\
\text { dosage form } \\
(\mu \mathrm{g} / \mathrm{ml})\end{array}$ & $\begin{array}{l}\text { pure OFL } \\
\text { added ( } \mu \mathrm{g} / \\
\mathrm{ml})\end{array}$ & $\begin{array}{l}\text { pure ORN } \\
\text { added ( } \mu \mathrm{g} / \\
\mathrm{ml})\end{array}$ & $\begin{array}{l}\text { total OFL } \\
\text { found ( } \mu \mathrm{g} / \\
\mathrm{ml})\end{array}$ & $\begin{array}{l}\text { total ORN } \\
\text { found }(\mu \mathrm{g} / \\
\mathrm{ml})\end{array}$ & $\begin{array}{c}\text { pure OFL } \\
\text { recovered \% } \\
\pm S . D^{*}\end{array}$ & $\begin{array}{c}\text { pure ORN } \\
\text { recovered \% } \\
\pm \mathrm{S} . \mathrm{D}^{*} \\
\end{array}$ \\
\hline \multirow{3}{*}{ ORNI O tab } & 5 & 12.5 & 4 & 10 & 9.07 & 22.67 & $100.78 \pm 1.17$ & $101.56 \pm 1.60$ \\
\hline & 5 & 12.5 & 5 & 12.5 & 10.14 & 24.52 & $101.37 \pm 1.78$ & $97.85 \pm 1.57$ \\
\hline & 5 & 12.5 & 6 & 15 & 11.24 & 27.08 & $102.20 \pm 0.87$ & $98.66 \pm 1.54$ \\
\hline \multirow{3}{*}{ OSNO O tab } & 5 & 12.5 & 4 & 10 & 8.97 & 22.86 & $99.68 \pm 0.65$ & $102.55 \pm 1.35$ \\
\hline & 5 & 12.5 & 5 & 12.5 & 10.04 & 24.79 & $100.24 \pm 1.08$ & $99.45 \pm 0.79$ \\
\hline & 5 & 12.5 & 6 & 15 & 11.1 & 27.39 & $101.57 \pm 0.67$ & $99.56 \pm 1.31$ \\
\hline \multirow{3}{*}{$\begin{array}{c}\text { OFLOX OZ } \\
\text { Tab }\end{array}$} & 5 & 12.5 & 4 & 10 & 9.12 & 23.01 & $101.53 \pm 1.12$ & $103.35 \pm 1.40$ \\
\hline & 5 & 12.5 & 5 & 12.5 & 9.95 & 24.71 & $99.15 \pm 0.81$ & $98.56 \pm 1.23$ \\
\hline & 5 & 12.5 & 6 & 15 & 11.31 & 28.12 & $102.81 \pm 0.96$ & $103.65 \pm 1.35$ \\
\hline \multicolumn{9}{|c|}{ DUAL WAVELENGTH METHOD } \\
\hline \multirow[t]{2}{*}{ Dosage form } & $\begin{array}{l}\text { OFL in dosage } \\
\text { form }(\mu \mathrm{g} / \mathrm{ml})\end{array}$ & $\begin{array}{l}\text { ORN in } \\
\text { dosage form } \\
(\mu \mathrm{g} / \mathrm{ml})\end{array}$ & $\begin{array}{c}\text { pure OFL } \\
\text { added }(\mu \mathrm{g} / \mathrm{ml})\end{array}$ & $\begin{array}{c}\text { pure ORN } \\
\text { added ( } \mu \mathrm{g} / \mathrm{ml})\end{array}$ & $\begin{array}{c}\text { total OFL } \\
\text { found }(\mu \mathrm{g} / \mathrm{ml})\end{array}$ & $\begin{array}{c}\text { total ORN } \\
\text { found }(\mu \mathrm{g} / \mathrm{ml})\end{array}$ & $\begin{array}{c}\text { pure OFL } \\
\text { recovered } \% \pm \\
\text { S.D* }\end{array}$ & $\begin{array}{c}\text { pure ORN } \\
\text { recovered } \% \pm \\
\text { S.D* }\end{array}$ \\
\hline & 5 & 12.5 & 4 & 10 & 8.94 & 22.45 & $99.68 \pm 1.32$ & $99.56 \pm 0.54$ \\
\hline \multirow{3}{*}{ ORNI O tab } & 5 & 12.5 & 5 & 12.5 & 10.15 & 24.97 & $102.35 \pm 2.21$ & $99.97 \pm 0.41$ \\
\hline & 5 & 12.5 & 6 & 15 & 11.15 & 27.58 & $102.31 \pm 1.31$ & $100.56 \pm 0.67$ \\
\hline & 5 & 12.5 & 4 & 10 & 9.21 & 22.68 & $101.54 \pm 0.59$ & $101.38 \pm 0.98$ \\
\hline \multirow[t]{2}{*}{ OSNO O tab } & 5 & 12.5 & 5 & 12.5 & 10.26 & 25.39 & $102.49 \pm 0.85$ & $102.65 \pm 2.14$ \\
\hline & 5 & 12.5 & 6 & 15 & 11.05 & 27.35 & $100.56 \pm 0.47$ & $101.23 \pm 0.65$ \\
\hline \multirow{3}{*}{$\begin{array}{c}\text { OFLOX OZ } \\
\text { Tab }\end{array}$} & 5 & 12.5 & 4 & 10 & 8.89 & 22.61 & $98.75 \pm 0.97$ & $101.96 \pm 1.25$ \\
\hline & 5 & 12.5 & 5 & 12.5 & 10.18 & 24.97 & $102.59 \pm 1.36$ & $99.85 \pm 1.56$ \\
\hline & 5 & 12.5 & 6 & 15 & 11.26 & 27.47 & $102.36 \pm 1.50$ & $99.79 \pm 0.69$ \\
\hline \multicolumn{9}{|c|}{ SIMULTANEOUS EQUATION METHOD } \\
\hline \multirow[t]{2}{*}{ Dosage form } & $\begin{array}{l}\text { OFL in dosage } \\
\text { form }(\mu \mathrm{g} / \mathrm{ml})\end{array}$ & $\begin{array}{c}\text { ORN in } \\
\text { dosage form } \\
(\mu \mathrm{g} / \mathrm{ml})\end{array}$ & $\begin{array}{c}\text { pure OFL } \\
\text { added ( } \mu \mathrm{g} / \mathrm{ml})\end{array}$ & $\begin{array}{c}\text { pure ORN } \\
\text { added ( } \mu g / m l)\end{array}$ & $\begin{array}{c}\text { total OFL } \\
\text { found ( } \mu \mathrm{g} / \mathrm{ml})\end{array}$ & $\begin{array}{l}\text { total ORN } \\
\text { found }(\mu \mathrm{g} / \mathrm{ml})\end{array}$ & $\begin{array}{c}\text { pure OFL } \\
\text { recovered \% } \% \\
\text { S.D* }\end{array}$ & $\begin{array}{c}\text { pure ORN } \\
\text { recovered } \% \pm \\
\text { S.D* }\end{array}$ \\
\hline & 5 & 12.5 & 4 & 10 & 8.85 & 22.45 & $98.35 \pm 1.45$ & $99.65 \pm 1.41$ \\
\hline \multirow[t]{3}{*}{ ORNI O tablet } & 5 & 12.5 & 5 & 12.5 & 9.96 & 25.68 & $99.57 \pm 0.58$ & $98.76 \pm 1.36$ \\
\hline & 5 & 12.5 & 6 & 15 & 10.75 & 27.69 & $97.65 \pm 1.25$ & $98.65 \pm 1.52$ \\
\hline & 5 & 12.5 & 4 & 10 & 9.08 & 22.65 & $100.85 \pm 0.69$ & $101.56 \pm 1.51$ \\
\hline \multirow[t]{2}{*}{ OSNO O tab } & 5 & 12.5 & 5 & 12.5 & 10.24 & 24.21 & $96.58 \pm 1.39$ & $97.54 \pm 1.39$ \\
\hline & 5 & 12.5 & 6 & 15 & 11.21 & 27.31 & $102.35 \pm 1.24$ & $102.65 \pm 0.37$ \\
\hline \multirow{3}{*}{$\begin{array}{c}\text { OFLOX OZ } \\
\text { Tab }\end{array}$} & 5 & 12.5 & 4 & 10 & 9.24 & 22.36 & $102.63 \pm 0.59$ & $99.25 \pm 0.77$ \\
\hline & 5 & 12.5 & 5 & 12.5 & 10.58 & 25.34 & $103.26 \pm 1.39$ & $97.38 \pm 0.64$ \\
\hline & 5 & 12.5 & 6 & 15 & 11.39 & 27.85 & $103.25 \pm 0.15$ & $102.36 \pm 2.15$ \\
\hline${ }^{*} \mathrm{~N}=3$ & & & & & & & & \\
\hline
\end{tabular}

Dissolution was carried in $0.01 \mathrm{~N} \mathrm{HCl}$ for three different tablets, samples were collected at 0,15 , 30,45 and 60 min intervals and the amount of drug dissolved was calculated by the developed three methods. The cumulative percentage of drug dissolved was plotted against time, shown in figures 5 \& 6 .

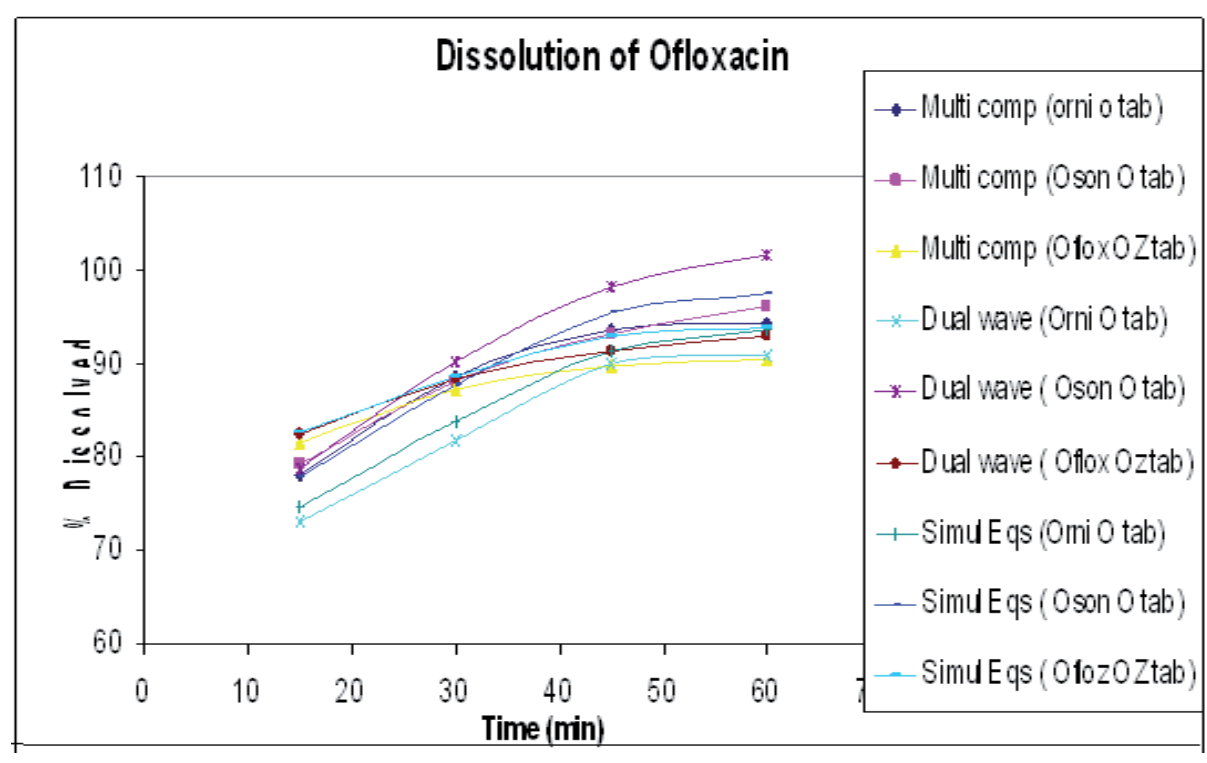

Figure 5. Dissolution profile comparison for OFL in three tablets by three methods

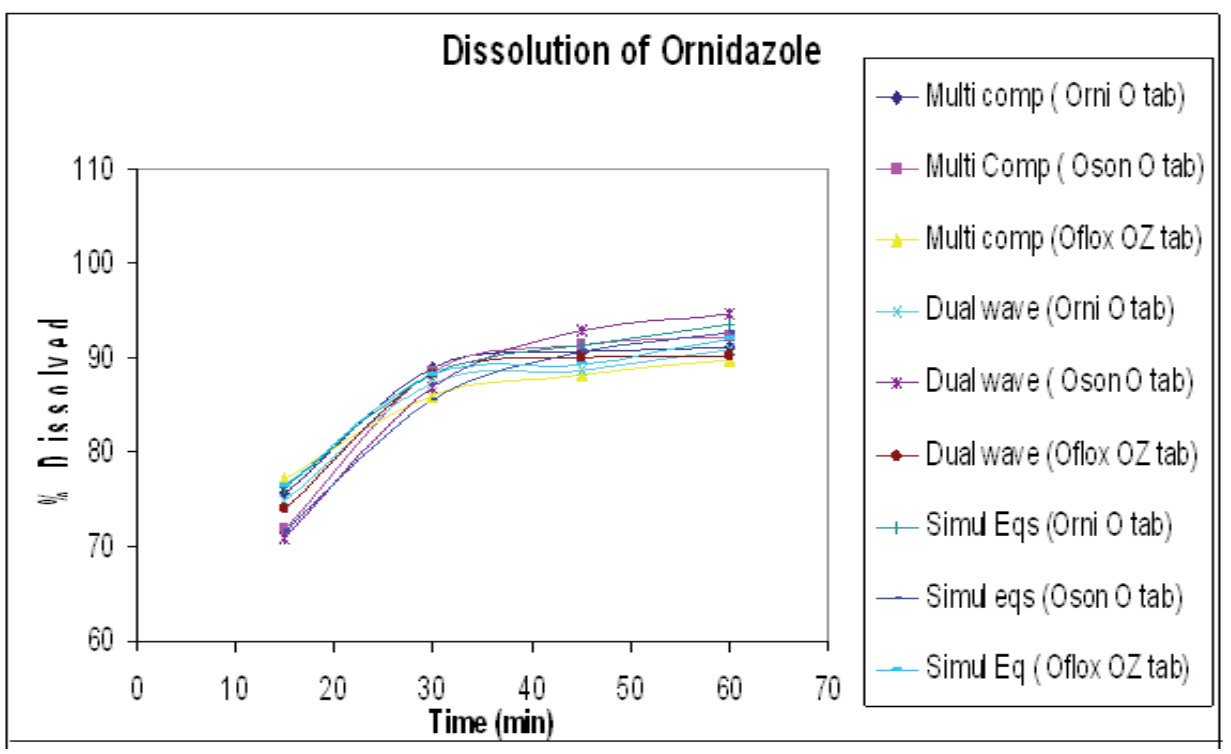

Figure 6. Dissolution profile comparison for ORN in three tablets by three methods

Ecl. Quím., São Paulo, 35 - 3: 123 - 132, 2010 


\section{Conclusions}

The analytical methods developed and validated for the simultaneous estimation and for dissolution testing of ofloxacin and ornidazole tablet dosage forms were considered satisfactory. The conditions that allowed the dissolution determination were $900 \mathrm{ml}$ of $0.01 \mathrm{M} \mathrm{HCl}$, at $37.0 \pm 0.5^{\circ} \mathrm{C}$, paddle apparatus, $50 \mathrm{rpm}$ stirring speed. The \% drug delivery was higher than $80 \%$ in 30 minutes for all evaluated products. The analysis of variance of the recovery of dosage forms and dissolution values showed that the methods developed were similar $(\mathrm{p}<0.05)$. The methods were validated and showed to be linear, precise and accurate.

\section{Acknowledgments}

We acknowledge our sincere thanks to GLPL, Vadodara.

\section{References}

[1] S. S.Incilay, T.Ayla, A nal. Lett., 36 (2003) 1163-1181.

[2] M. D.Bethesda, Directors of the American Society of Hospital Pharmacists.

[3] Drug information USA, 88 (1988) 415-420.

[4] Proceedings of the World Health Organisation Meeting on Use of Quinolones in Food

[5] Animals and Potential Impact on Human Health, Geneva, Switzerland, (1998).

[6] A. Kucers, S. M. Crowe, M. L.Graysan, J. F. Hoy, The Use of Antibiotics, 55th Edn., 1997.

[7] P. S. Francis, J. L. Adcock, Analytica Chimica Acta, 54 (2005) 3-12.

[8] P. Gao, J. Shi, J. N. Li, S. M. Liu, Chin. J. Appl. Chem., 22 (2005) 578-580.

[9] C. L. Tong, G. H. Xiang, D. J. Huang, W. P. Liu, Chin. J. Anal. Chem., 32 (2004) 619-621.

[10] R. G. Finch, Drugs, 49 (1995) 144-151.

[11] N. M. Lopez, A. M. Palermob, M. D. Mudryc, M. A. Carballo, Toxicol. In Vitro., 17 (2003) 35-40.

[12] H. M. Sílvia, P. Lutiane, Z. A. Marcela, B. Liziane, G. C. Simone, Sci. Pharm., 76 (2008) 541-554.

[13] J. Emami, J. Pharm. Sci., 9 (2006) 169-189.

[14] M. D. Rockville, FDA Guidance for Industry, 1997.

[15] British pharmacopoeia, Licensing division HMSO, Norwich, (2003) 357.
[16] United State Pharmacopoeia, United State Pharmacopoeial Convention, (2007) 1355.

[17] European Pharmacopoeia, EDQM, Council of Europe, Strasbourg, $5^{\text {th }}$ edn., (2005) 2131.

[18] V. M. Shinde, B. S. Desai, N. M. Tendolkar, Indian Drugs, 35 (1998) 715.

[19] A. P. Argekar, U. S. Kapadia, S. V. Raj, S. S. Kunjur, Indian Drugs, 33 (1996) 261.

[20] Y. S. Krishnaiah, M. Y. Indira, P. Bhaskar, Journal of Drug Targeting, 11 (2003)109.

[21] P. U. Patel, B. N. Subaghia, M. M. Patel, Indian Drugs, 93 (2004) 28.

[22] M. Bakshi, B. Singh, A. Singh, S. Singh, J. Pharm. B iomed. A nal., 26 (2001) 891.

[23] A. Behl, M. Ahuja, A. S. Dhake, Indian J. Pharm. Sci., 67 (2005) 479.

[24] N. S. Kamble, B. Venkatachalam, Indian Drugs, 42 (2005) 723.

[25] M. Gandhimathi, T. K. Ravi, S. Nilima, Indian J. Pharm. Sci., 68 (2006) 838-840. 